\title{
The Mediational Role of Task Performance in the Relationship between Perceived Organizational Support and Organizational Citizenship Behaviour among Secondary School Teachers
}

\author{
Israel Kamoga Simon Nantamu $^{2} \quad$ Leonsio Matagi $^{2} \quad$ Joyce Nansamba $^{2}$
}

\begin{abstract}
Purpose - The purpose of this paper is examine the relationship between Perceived Organizational Support (POS), task performance (TP) and Organizational Citizenship Behavior (OCB) among secondary school teachers in selected schools.

Design/methodology/approach - This study utilized a cross-sectional research design and a quantitative method to collect data from 261 participants using convenience sampling technique.

A self- administered was used to collect data. Descriptive statistics were used to analyze the respondents' demographic characteristics, Pearson correlations were used to analyze relationships between the variables and mediation was analyzed using the 3 -step regression analysis.

Findings - The results suggest that there is a positive significant relationship between POS and task performance, a positive significant relationship between POS and OCB, a positive significant relationship between task performance and OCB, and task performance partially mediates the relationship between POS and OCB.

Practical implications - Results will be used by head teachers of secondary schools to gain a clear understanding of the benefits of staff engaging in OCBs and how these behaviours can be achieved through POS and TP. Head teachers will design appropriate strategies for continuous quality improvement in the areas of OCBs, TP and POS. Originality/value - There is a dearth of literature on the mediating effect of TP in the relationship between POS and OCBs. Therefore, this study addressed this literature gap.
\end{abstract}

Keywords - Perceived Organizational Support, Task performance and Organizational Citizenship Behaviour.

Paper type - Research paper

DOI: $10.7176 / \mathrm{EJBM} / 14-3-04$

Publication date: February $28^{\text {th }} 2022$

\subsection{Introduction}

Of recent, the educational sector is moving into an age of reorganization, which demands to work in a competitive and complex environment (Shaheen, Gupta, and Kumar, 2016). A school is successful and has competitive edge over other schools when it has teachers who are committed to the goals and values of school (Somech and Ron, 2007), and are willing to go beyond the call of duty (OCB). Organizational Citizenship Behaviour (OCB) refers to individual behaviour that is discretionary, not directly or clearly recognized by the formal reward system, and collectively promotes the efficient and effective functioning of the organization (Organ, Podsakoff, and MacKenzie, 2005). Discretionary means that the behaviour is not an enforceable requirement of the role or the job description, rather it is a personal choice such that its omission is not generally understood as punishable (Sharma and Agrawal, 2015). Previous studies also show that OCB helps in enhancing productivity, facilitates organizations to compete regardless of limited resources, also helps in better coordination among employees thus also helping the organization to overcome employee turnover, enhance organization adaptability, increase profitability and customer satisfaction (Koys, 2001; Podsakoff and MacKenzie, 1994). Specifically, the role of OCB is crucial in the knowledge-based economy, where due to the rapidly evolving nature of the external environment, there is less role clarification. In these situations, organizations increasingly look to their employees' in filling the gap between what they, in particular, are awarded for and the emergent behaviours required for the organization to be competitive (Dekas et al., 2013). According to Rose (2016), OCB has a significant role in contributing to the organization's performance through the social systems existing at any workplace. It also facilitates the enhancement of work of teams and groups, specifically in those groups which are having an internal dependency on its members. OCB has also its contribution to individuals' performance by giving them an indication about an individual's helpfulness, reliable and cooperative nature. Thus, OCB can be enhanced by development activities like workplace learning, mentoring and productive feedback (Rose, 2016).

Garg and Rastogi's (2006) empirical study on teachers' OCB in both public and private schools of India showed that teachers are involved in activities beyond the job behavior to fulfill the new standards of educational policies. They concluded that teacher's OCBs do contribute to the overall effectiveness of the school and aid in promoting professionalism and academic excellence within schools. Similarly, Bangotra (2016), stated that in today's dynamic school environment, teachers are not only educators but they are now supporters to the students, facilitators in class and advisors to the parents. This shows that teachers handle multiple roles and do not restrict themselves to be simply knowledge providers (Shaheen et al., 2016). With the passage of the No Child Left Behind 
Act of 2001 of the United States, teachers and administrators are being asked to do whatever it takes in order to help increase student achievement (Martinez, 2012). To achieve this, teachers work for very long hours despite the increasing student population with the same number of teachers. This means going beyond their job descriptions. In fact, schools do not recognize OCB and therefore it's not rewarded (Ahmadi, Forouzandeh, and Kahreh, 2010). As a result, teachers reluctantly engage in OCB because they feel that their efforts are not recognized which in turn has led the teachers perceiving that their school (organization) is not supportive.

Perceived Organizational Support (POS) is conceptualized as employees' perceptions regarding the extent to which their organizations give support to their employees and the extent of the organizations' readiness to provide assistance when needed. If the employees perceive that their organization is highly supportive, then they will probably absorb their membership of the organization into their identities, and then develop a relationship and a more positive perception about their organization. The fusing of the employee's membership in the organization with the employee's identity makes the employee feel part of the organization, and that he/she has a responsibility to contribute and deliver his/her best performance for the organization (Rhoades and Eisenberger, 2002). Strong organizational support leads employees to increase their efforts for company success (Polatç1, 2015).

Monnastes (2010) indicated that if employees feel that they are supported by the organization, they will feel obligated to care about that organization's well-being thereby putting effort to assist the organization to succeed and achieve its goals. In most cases, employees who perceive that their organization is supportive show higher performance and proactive behaviours ( Arshadi and Hayavi, 2013; Caesens, Marique, Hanin, and Stinglhamber, 2016; Eisenberger, Cummings, Armeli, and Lynch, 1997; Riggle et al., 2009). In a systematic review of 70 studies, Rhoades and Eisenberger (2002) indicated that positive organizational support is related to fair organizational procedures, supervisor support, and favourable rewards and job conditions, which in turn lead to positive outcomes for both the individual and the organization, such as increased performance. Another study and meta-analysis were conducted on POS pointing out its antecedents revealed that POS was mainly linked to justice, growth opportunities, supervisor support, and coworkers support. Kurtessis et al., (2015) also performed a meta-analysis, which reveals that job conditions played a substantial role in establishing POS, with employees being inclined to POS as a way to reciprocate adequate working conditions (Shore et al., 2006; Kurtessis et al., 2015). In addition, Kurtessis et al.'s (2015) study posited that POS is connected to favourable social interactions, both with colleagues and supervisors, with the latter more significant because leaders are perceived as representative of the organizations (Stinglhamber and Vandenberghe, 2003).

Task Performance (TP) is concerned with the effectiveness with which job incumbents perform activities that contribute to the organization's technical core either directly by implementing a part of its technological process, or indirectly by providing it with needed materials or services (Borman and Motowidlo, 1993). Thus, Task Performance covers the fulfilment of the requirements that are part of the contract between the employer and employee. Examples of Task Performance (TP) or in-role behaviors in schools are teaching, conducting classes on time, monitoring fair evaluation of students, maintaining discipline in class and schools (Somech and Oplatka, 2014; Somech and Ron, 2007). Empirical studies have shown that employees who perceive the organization as being supportive have high TP than those who do not perceive the organization as being supportive. For instance, Rhoades and Eisenberger, (2002) meta-analysis results indicated that POS was found to be positively related to evaluative and objective measures of performance in standard job activities (TP). Furthermore, empirical findings indicate that employees with high POS have been found to demonstrate greater effort on behalf of the organization (Kurtessis et al., 2015), higher in-role or TP (Cullen, Edwards, Casper and Gue, 2014), and engage more in OCBs (Wayne, Shore, and Liden, 1997). Therefore, if schools do not work hard to create an environment that supports its teachers, then there will be continued deterioration of TP and low engagement in OCBs of the teachers.

In many schools today, teachers feel that their efforts such as providing special attention to weak students, counseling students, supporting fellow teachers to complete their school work, or an on request to take classes of their fellow teacher in their absence (Somech and Oplatka, 2014; Somech and Ron, 2007), are not recognized despite helping the school in achieving its goals and objectives. This can be attributed to the lack of a good structure to support staff and appraise their performance. Consequently, this has led to the continued deterioration of TP and OCB among teachers in schools resulting into low grades, low motivation and high rate of dropouts from schools (Smith et al., 2008), poor delivery of school services which has in turn affected the efficiency and effectiveness of the school.

The study adds knowledge to the existing body of literature on POS, TP and OCBs. Results will be used by head teachers of secondary schools to gain a clear understanding of the benefits of staff engaging in OCBs and how these behaviours can be achieved through POS and TP. Head teachers will design appropriate strategies for continuous quality improvement in the areas of OCBs, TP and POS.

The remainder of the paper is structured as follows. In the next section, we present the literature review for the study and develop research hypotheses. Next, we present the method and measures adopted. This is followed by data analysis, results and discussion. Finally, implications for theory and practice, limitations and avenues for future research are presented. 


\subsection{Conceptual framework and research hypotheses}

\subsection{The conceptual framework}

The framework indicates the relationship among three variables. POS which is the independent variable, OCB which is the dependent variable, and TP which is the mediating variable.

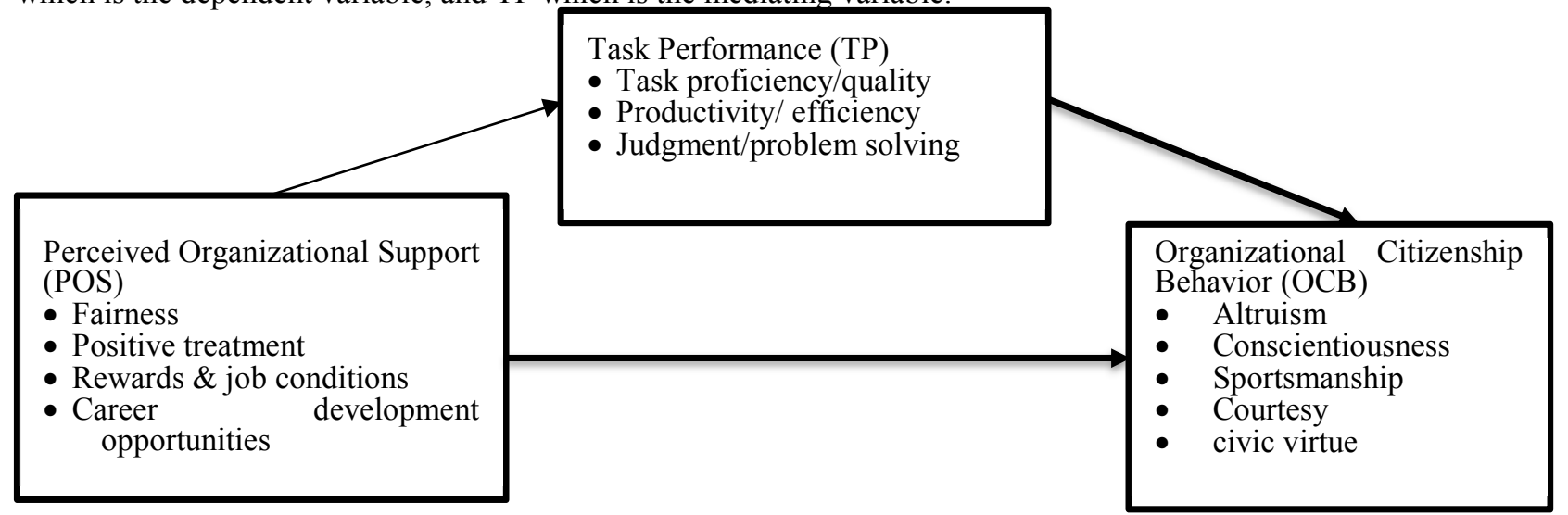

Figure 1. The conceptual model

The conceptual framework denotes that POS influences TP in that when employees perceive the organization as being supportive (POS) in terms of fairness, positive treatment, rewards and good job conditions, they are more likely to increase their TP in terms of task proficiency, problem solving, and exhibiting high productivity (Eisenberger, Armeli, Rexwinkel, Lynch, and Rhoades, 2001). As a result, they are likely to engage in OCBs such as helping specific co-worker (altruism), work extra hours (conscientiousness), or go ahead to help other coworkers to prevent falling into problems through advice (courtesy) (Chen, Eisenberger, Johnson, Sucharski, and Aselage, 2009). Finally, POS will also affect OCB through TP. This implies that TP will mediate the relationship between POS and OCBs.

\subsection{POS and TP}

While prior research inconsistently finds a positive relationship between POS and TP, there still exists very little empirical literature on this relationship. This study addressed this gap in the literature. For example, Rhoades and Eisenberger, (2002) meta-analysis findings reported that POS was found to be positively related to evaluative and objective measures of performance in standard job activities (TP). However, results from a study done by Stamper and Johlke, (2003) showed that POS was not related to TP. In studies done by Byrne and Hochwater, (2008), a modest relationship between POS and TP was reported. In a meta-analysis by Riggle, Edmondson, and Hansen (2009) indicated that POS has a moderate, positive effect on TP. Study findings by Arshadi, (2011) showed that POS was positively related to in-role performance (TP). A study by Akcin, Erat, Alniacik, and Ciftcioglu, (2017) revealed that there is a positive significant relationship between POS and TP, implying that as POS increases, TP also increases. When employees see their organization as supportive, their performance increase (Eisenberger et.al., 1997; Caesens et.al., 2016).

\section{$H_{1}:$ There is a positive significant relationship between POS and TP among secondary school teachers.}

\subsection{POS and OCB}

Several empirical studies have reported statistically significant associations between POS and OCB (Moorman, Blakely, and Niehoff, 1998; Shore and Wayne, 1993). However, in recent years, there are inconsistences in the empirical findings in the relationship between POS and OCB. Furthermore, the existing literature has very few empirical studies on the relationship between POS and OCB in the education sector. This represents a significant gap in the literature and therefore, this study addressed this literature gap.

The study by Shore and Wayne (1993) found out that POS becomes a predictor of OCB and is positively related to performance and OCB. Workers who feel supported by their organization reciprocate this feeling and thus lower the imbalance in the relationship by engaging in citizenship behaviour. Settoon, Bennett, and Liden, (1996) and Wayne, Shore, and Liden, (1997) reported positive relationships between POS and employee citizenship behaviour in their models. Similarly, Masterson, Lewis, Goldman, and Taylor, (2000) found a significant relationship between POS and organization-directed OCBs. Kaufman, Stamper, and Tesluk (2001) reported a significant POS-OCB relation-ship in their studies. Studies have used POS alone to predict behaviours such as extra-role behaviours and found a significant relationship between POS and OCB (Eisenberger et al., 2002; Eisenberger et al., 2001; Shore and Wayne, 1993).

In a meta-analysis done by Rhoades and Eisenberger (2002), POS was found positively related to extra-role performance $(\mathrm{OCB})$ such as conscientiousness in carrying out job responsibilities, help for coworkers and creative 
suggestions for the organization's operations (Eisenberger et al., 1990; Lynch, Eisenberger, and Armeli, 1999; Moorman, Blakely, and Niehoff, 1998; Shore and Wayne, 1993; Wayne, Shore, and Liden, 1997). Study of Wayne et al. (2002) portray that POS precisely predicts the OCB of an employee. Moreover, the study further concluded that employee develops trust in their organization when they feel that they are important to the organization. They become active participants and offer a concrete suggestion for the development of the organization.

Wayne, Shore, Bommer, and Tetrick's (2002) study revealed that POS has a strong relationship with OCB. The study proposed that POS is associated with two OCB's dimensions, altruism and compliance dimensions. The results of (Cardona et al., 2004) study, confirmed that the individuals with high POS had a solid social connection with their organization, which in turn increased their OCB. Research carried out on POS after this meta-analysis continues to support the conclusion that there is a positive relation between POS and extra-role performance (OCB) (Byrne and Hochwarter, 2006; Wayne, Shore, Bommer, and Tetrick, 2002). An Iranian study suggested that POS induced a positive effect on OCB (Asgari, Silong, Ahmad, and Samah, 2008).

The results of studies investigating POS as a predictor of extra-role behaviors (OCB) show a positive relationship between POS and OCBs, suggesting that increased perceptions of organizational support are likely to lead to employees displaying more extra-role behaviours (OCB) (Eisenberger, Johnson, Sucharski, and Aselage, 2009; Rhoades and Eisenberger, 2002). Miao and Kim (2010) and Chiang and Sheng (2011) also found a significant relationship between POS and OCB. Chiang and Hsieh's (2012) findings in their study indicated that POS positively affected OCB. A study conducted by Nisar, Marwa, Ahmad, and Ahmad (2014) showed that POS is exceedingly positively and significantly correlated with OCB. Chiaburu, Chakrabarty, Wang and Li (2015) conclude in their study that there is a significant positive relationship between POS and OCB. In meta-analysis study by Ahmed et al. (2015) on the outcomes of POS, the findings showed that POS has an effect on OCB. The recent empirical findings contradict prior empirical findings of studies on the relationship between POS and OCB. For example, recently, Fouzia, Sayyid, Ishfaq, and Madiha's (2018) study indicated that there is no significant correlation between POS and OCB. These findings are contradictory to many prior empirical findings.

\section{$H_{2}$ : There is a positive significant relationship between POS and OCB among secondary school teachers.}

\subsection{TP and OCB}

Although research has consistently shown a significant relationship between TP and contextual performance (Cropanzano et al., 2003), there still exists little empirical literature on the relationship between TP and OCB especially in the education sector where researchers have paid little attention to this relationship. This indicates a significant literature gap and therefore this study addressed this gap in literature.

Dipola and Tschannen-Moran (2001) conducted research among 1,874 teachers in public schools in Ohio and Virginia, and concluded that teachers are working towards the achievement of overall organizational goals exhibit high TP, while at the same helping other teachers and students (OCB). In another study, it was found that teachers who had a high sense of status in their work (high TP) tended to invest in more OCBs than other teachers (Bogler and Somech, 2004). Findings of Shih (2007) have shown that the higher the OCB, the higher the TP. In Podsakoff et al.'s (2009) meta-analysis, findings indicated a positive overall relationship between OCB and TP. A study by Nasir, Mohammadi, Wan Shahrazad, Fatimah, Khairudin, and Halim (2011) indicated that there is a significant relationship between all the five dimensions of OCB and TP. Results from Diaz-Vilela et al., (2015) study indicated that there is a high positive correlation between TP and contextual performance (OCB).

\section{$H_{3}$ : There is a positive significant relationship between TP and OCB among secondary school teachers.}

\subsection{The mediating effect of TP on the relationship between POS and OCB.}

There is a dearth of literature on the mediating effect of TP in the relationship between POS and OCB despite the substantial amount of research largely conducted on task performance. This study addressed this literature gap. However, there are a few empirical studies where TP has mediated relationships between different variables. For example findings of Salahat and Abdul Halim, (2017) indicated that TP partially mediates the link between Performance Appraisal and Customer Satisfaction, and also in the same study, results showed that TP mediates the relationship between Internal Communication and Customer Satisfaction. They particularly used a five Likert TP scale adopted from Tjosvold and Yu (2004) to measure TP in their study.

$H_{4}$ : TP significantly mediates in the relationship between POS and $O C B$ among secondary school teachers.

\subsection{Methodology}

\subsection{Design and sample}

A cross-sectional survey design was adopted because it best served to answer the purposes of the study. The respondents in the target population consisted of only permanent teaching staff in the selected schools because they are assumed to have the required information of this study.

A sample size of 201, selected using convenience sampling technique was obtained from a study population of 420 teachers using Krejcie and Morgan's (1970) scientific framework for determining sample size. It included: 
$132(50.4 \%)$ males and $130(49.6 \%)$ females; and majority were: above 30 years of age $(65.7 \%)$, married (59.5\%); had work experience of above 10 years (53.4\%), and had a bachelor's or a master's degree (86.6\%).

\subsection{Instruments and measures}

A structured self-administered questionnaire was used with closed-ended items and responses designed in a Likert fashion. The questionnaire was made up of four sections. Section A captured bio-data (e.g. gender, age, marital status, education level, professional grade, work experience and designation), section B measured Perceived Organizational Support (POS), section C measured Task Performance (TP) and section D measured Organizational Citizenship Behaviors (OCB).

Perceived Organizational Support (POS) was assessed using an eight-item shortened version of Eisenberger et al., (1986). Examples are "My organization values my contribution to its well-being" and "My organization strongly considers my goals and values". Responses were based on a five-point Likert scale (where $1=$ strongly disagree to $5=$ strongly agree). The reliability coefficient (Cronbach alpha) for this scale initially was .97 . Other researchers who have used this POS scale are Uçar and Otken, (2010) obtained a Cronbach Alpha of .88, Okeke and Emma-echiegu, (2018) obtained a Cronbach Alpha of .89, and Gakovic and Tetrick, (2019) obtained a Cronbach Alpha of .86.

Task Performance (TP) was measured using a seven-item scale adapted from a 21-scale developed by Williams and Anderson (1991). Examples of items are "I adequately complete the assigned duties", and "I perform tasks that are expected of me". Responses were based on a five-point Likert scale (where $1=$ strongly disagree to $5=$ strongly agree). The reliability coefficient (Cronbach alpha) for this scale initially was .91 . Other researchers who have previously used this scale are Pulfrey, Darnon, and Butera, (2013) and obtained Cronbach Alpha of .87; Miao, (2011) obtained Cronbach Alpha of .69.

Organizational Citizenship Behaviors (OCB) was measured using a shortened 20-item OCB scale (Podsakoff et al., 1990). The scale captured all the five OCB dimensions identified by Organ (1988) namely: altruism, conscientiousness, sportsmanship, courtesy and civic virtue. Examples are "I help others who have heavy workloads" and "I am always ready to lend a helping hand to those around me". Responses were based on a fivepoint Likert scale (where $1=$ strongly disagree to $5=$ strongly agree). The reliability coefficient for this measure initially was .76. Other researchers who have previously used this scale are; Miao, (2011) obtained a Cronbach alpha of .80, Argentero, Cortese, and Ferretti, (2008) obtained Cronbach alpha of .84, Hui, Lee and Rousseau, (2004) and Lam, Hui and Law, (1999) obtained Cronbach alpha between .84 and .88.

\subsection{Data analysis}

After coding, the data was entered and analyzed using Statistical Package for Social Sciences (IBM SPSS) Version 23. Data was cleansed of errors. The data was checked for missing values using frequencies. The option of excluding cases pairwise was used to deal with the missing data during analysis. Reverse coding all negative items in two scales (POS and TP) was done. All item of the POS scale (1-8) were reverse coded, items (6 and 7) of the TP scale were also reverse coded. Normality tests of skewness and kurtosis were run to make sure that the assumptions of parametric testing are not violated.

Table I below shows that: POS had a skewness of .16 $(S E=.15)$ and a kurtosis of .07 $(S E=.31)$; TP had a skewness of $.14(S E=.15)$ and a kurtosis of $-.37(S E=.30)$; and OCB had a skewness of .13 $(S E=.16)$ and a kurtosis of -.17 $(S E=.32)$. All the skewness and kurtosis values fall in an acceptable range of $\pm 1($ Hair et al., 2010; Huck, 2004) and also fall in the normal range of $Z$ - values of \pm 1.96 (Aron, Coups, and Aron, 2013). The data therefore revealed approximately normal distributions.

Table I: Normality results of skewness and kurtosis

\begin{tabular}{lcccc}
\hline Variable & Skewness & Std. Error $(\boldsymbol{S E})$ & Kurtosis & Std. Error $(\boldsymbol{S E})$ \\
\hline POS & .16 & .15 & .07 & .31 \\
TP & .14 & .15 & -.37 & .30 \\
OCB & .13 & .16 & -.17 & .32 \\
\hline
\end{tabular}

\subsection{Results}

\subsection{Correlation results}

Table II indicates: a positive significant relationship between POS and PT ( $\mathrm{r}=.46 ; \mathrm{p}<.01)$, and $\mathrm{H}_{1}$ is supported; a positive significant relationship between POS and OCB $(\mathrm{r}=.37 ; \mathrm{p}<.01)$, and $\mathrm{H}_{2}$ is supported; and positive significant relationship between TP and OCB $(r=.57 ; \mathrm{p}<.01)$, and $\mathrm{H}_{3}$ is supported; 
Table II: Correlation results indicating the relationship between POS and TP.

\begin{tabular}{|c|c|c|c|}
\hline Variables & 1 & 2 & 3 \\
\hline 1. POS & .89 & & \\
\hline 2. TP & $.46^{* *}$ & .65 & \\
\hline 3. $\mathrm{OCB}$ & $.37^{* *}$ & $.57^{* *}$ & .75 \\
\hline
\end{tabular}

** Significant at the 0.01 level (2-tailed); Bold italicized diagonal values are reliability coefficients.

\subsection{Multiple regression results}

Step 1 in Table III shows that the regression of POS predicting OCB, ignoring the mediator (TP) was significant, $b=.49, t(222)=5.86, p \leq .001$. POS also explained $13 \%$ of variance in $\operatorname{OCB} F(1,222)=34.32, p<.001$.

Table III: Step 1-POS and OCB

\begin{tabular}{|c|c|c|c|c|c|c|c|c|c|c|}
\hline \multirow{2}{*}{\multicolumn{2}{|c|}{ Model }} & \multicolumn{2}{|c|}{$\begin{array}{c}\text { Unstandardized } \\
\text { Coefficients }\end{array}$} & \multirow{2}{*}{$\begin{array}{c}\text { Standardized } \\
\text { Coefficients } \\
\text { Beta }\end{array}$} & \multirow[b]{2}{*}{$\mathrm{t}$} & \multirow[b]{2}{*}{ Sig. } & \multirow{2}{*}{$\begin{array}{c}\text { Adjusted } \\
R^{2} \\
\end{array}$} & \multirow[b]{2}{*}{$F$} & \multirow[b]{2}{*}{ Sig } & \multirow[b]{2}{*}{$d f$} \\
\hline & & $\mathrm{B}$ & Std. Error & & & & & & & \\
\hline & (Constant) & 70.00 & 2.68 & & 26.09 & .00 & & & 1 & \\
\hline & POS & .49 & .08 & .37 & 5.86 & .00 & .13 & 34.32 & .00 & 222 \\
\hline
\end{tabular}

a. Dependent Variable: $O C B$

Step 2 in Table IV shows that the regression of POS predicting TP was significant, $b=.28, t(244)=8.18, p$ $<.001$. POS also explained $21 \%$ of variance in TP, $F(1,244)=66.89, p<.001$.

Table IV: Step 2-POS and TP.

\begin{tabular}{|c|c|c|c|c|c|c|c|c|c|}
\hline \multirow[b]{2}{*}{ Model } & \multicolumn{2}{|c|}{$\begin{array}{l}\text { Unstandardized } \\
\text { Coefficients }\end{array}$} & \multirow{2}{*}{$\begin{array}{l}\text { Standardized } \\
\text { Coefficients } \\
\text { Beta } \\
\end{array}$} & \multirow[b]{2}{*}{$\mathrm{t}$} & \multirow[b]{2}{*}{ Sig. } & \multirow{2}{*}{$\begin{array}{c}\text { Adjusted } \\
R^{2}\end{array}$} & \multirow[b]{2}{*}{$F$} & \multirow[b]{2}{*}{ Sig } & \multirow[b]{2}{*}{$d f$} \\
\hline & $\mathrm{B}$ & Std. Error & & & & & & & \\
\hline (Constant) & 21.82 & 1.09 & & 20.11 & .00 & & & 1 & \\
\hline POS & .28 & .03 & .46 & 8.18 & .00 & .21 & 66.89 & .00 & 244 \\
\hline
\end{tabular}

a. Dependent Variable: TP.

Step 3 in Table V shows that TP was a significant predictor of OCB, $b=1.11, t(219)=7.73, p<.001$. Results also show that controlling for the mediator (TP), POS was still a significant predictor of OCB, $b=.18, t(219)=$ $2.10, p=<.05$, indicating partial mediation, and $\mathrm{H}_{4}$ partially supported. POS also explained $31 \%$ of variance in OCB after controlling for TP, $F(2,219)=51.66, p<.001$. The result also shows a decrease in beta weight of the unstandardized coefficients from $b=1.11(p<.001)$ to $b=0.18(p<.05)$, and significantly different from 0 , which is also evidence for partial mediation.

Table V: Step 3-POS, TP, and OCB

\begin{tabular}{|c|c|c|c|c|c|c|c|c|c|c|}
\hline \multirow{2}{*}{\multicolumn{2}{|c|}{ Model }} & \multicolumn{2}{|c|}{$\begin{array}{l}\text { Unstandardized } \\
\text { Coefficients }\end{array}$} & \multirow{2}{*}{$\begin{array}{l}\text { Standardized } \\
\text { Coefficients } \\
\text { Beta }\end{array}$} & \multirow[b]{2}{*}{$\mathrm{t}$} & \multirow[b]{2}{*}{ Sig. } & \multirow[b]{2}{*}{ AdjustedR $^{2}$} & \multirow[b]{2}{*}{$F$} & \multirow[b]{2}{*}{ Sig } & \multirow[b]{2}{*}{$d f$} \\
\hline & & $\mathrm{B}$ & Std. Error & & & & & & & \\
\hline \multirow[t]{3}{*}{1} & (Constant) & 45.93 & 3.92 & & 11.73 & .00 & & & & \\
\hline & POS & .18 & .08 & .13 & 2.10 & .04 & & & 2 & \\
\hline & TP & 1.11 & .14 & .49 & 7.73 & .00 & .31 & 51.66 & .00 & 219 \\
\hline
\end{tabular}

a. Dependent Variable: $O C B$.

\subsection{Sobel test}

After analyzing mediation using the 3-Step regression analysis, Baron and Kenny (1986) recommended the use of the Sobel test (Sobel, 1982) to confirm the results obtained in the 3-step regression analysis. The Sobel test is used to test whether or not the total effect of the independent variable on the dependent variable is significantly reduced upon the addition of a mediator to the model (Preacher and Hayes, 2004). It tests the significance of the indirect effect (mediation effect). The Sobel test showed that the mediation effect was significant $(a b=0.2, z=6.04, p$ $<.001)$. This indicates that TP partially mediates in the relationship between POS and OCB.

\subsection{Discussion}

The study revealed a positive significant relationship between POS and TP. The findings suggest that the higher the teachers' POS, the higher their TP. Employees respond to favorable treatment by the organization with feelings of obligation to care about the organization's welfare and to act in the organization's behalf, which, in turn, enhance positive work attitudes and behaviors such as adequately completing their assigned duties (Arshadi, 2011). According to Coyle-Shapiro and Conway (2005), strong POS encourages individuals to develop their TP in supporting the realization of organizational objectives.

Research on social exchange theory has shown that employees who feel they have been well supported by their organizations tend to reciprocate by performing better than those reporting lower levels of POS (Eisenberger 
et al., 1990; Shore and Wayne, 1993). Polatçı (2015) noted that strong organizational support leads employees to increase their efforts for organizational success. Monnastes (2010) continues to say that if employees feel that they are supported by the organization, they will feel obligated to care about that organization's well-being thereby putting effort to assist the organization to succeed and achieve its goals. In most cases, employees who perceive that their organization is supportive show higher TP and proactive behaviours (Arshadi and Hayavi, 2013; Caesens et al., 2016 Eisenberger, Cummings, Armeli, and Lynch, 1997; Riggle et al., 2009).

A positive significant relationship between POS and TP is in support of Rhoades and Eisenberger's (2002) meta-analysis findings which indicated that POS was found to be positively related to evaluative and objective measures of performance in standard job activities (TP). Similarly, Byrne and Hochwater, (2008) reported a modest relationship between POS and TP, as well as Riggle, Edmondson and Hansen's (2009) meta-analysis findings which indicated that POS has a moderate, positive effect on TP. Unlike Arshadi (2011) who found out that POS is positively related to in-role performance (TP), Stamper and Johlke's (2003) findings which showed that POS is not related to TP.

A positive significant correlation between POS and OCB depict the significant role of organizational support which motivates employees to work beyond their tasks and engage in extra role-performance. This means that an employee may reciprocate support from the organization through engaging in extra role behaviors such helping others who have heavy workloads (Konovsky and Pugh, 1994; Spector and Che, 2014). Employees perceiving high levels of organizational support always have an obligation to the organization's welfare and they believe that good performances will be recognized and rewarded. They therefore often work beyond their organizational roles (Rhoades and Eisenberger, 2002). The study concurs with the findings of previous researchers such as Wayne et al. (2002) who found a positive significant relationship between POS and OCB. They portrayed that POS precisely predicts the OCB of an employee, and that employees develop trust in their organization when they feel that they are important to the organization. They become active participants and offer a concrete suggestion for the development of the organization.

In the same way, Cardona et al., (2004) who found a positive significant relationship between POS and OCB confirmed in their study that the individuals with high POS had a solid social connection with their organization, which in turn increased their OCB. In addition, Eisenberger, Johnson, Sucharski, and Aselage, (2009) and Rhoades and Eisenberger, (2002) who investigated POS as a predictor of extra-role behaviors (OCB) obtained significant positive relationships between POS and OCB. Even Cheung (2013) obtained a positive significant relationship between POS and OCB. Similar findings were obtained by Ahmad, and Ahmad (2014), Ahmed et al. (2015), Chiang and Hsieh's (2012), Chiang and Sheng (2011), Miao and Kim (2010), and Nisar, Marwa, Chiaburu, Chakrabarty, Wang and Li (2015). Cheung, (2013) concluded that OCBs can be viewed as a result of the social exchange process in which employees perceive the obtainability of organizational assistances and care as a result of fair relational and instructive treatment. Very few researchers, e.g. Fouzia, Sayyid, Ishfaq, and Madiha's (2018), did not find a significant correlation between POS and OCB.

There was a positive significant correlation between TP and OCB. This is in agreement with Dipola and Tschannen-Moran (2001) study who concluded that teachers who are working towards the achievement of overall organizational goals exhibit high TP, while at the same time helping other teachers and students (OCB). Bogler and Somech (2004) also found that teachers who had a high sense of status in their work (high TP) tended to invest in more OCBs than others who had a low sense of status in their work (low TP). The study's results also corroborate with the results yielded by Podsakoff et al., (2009) meta-analysis findings, Nasir et al., (2011), Diaz-Vilela et al., (2015) and Saraih and Lim, (2017) also found positive correlation between TP and OCB.

TP partially mediates the relationship between POS and OCB among secondary school teachers. POS has an indirect positive effect on OCB through TP. When employees perceive that their organization is being supportive, they will go beyond their normal tasks expected of them and engage in extra-role behavior (OCB) but the level of engagement in the extra-role behaviors is also largely influenced by their TP.

\subsection{Conclusion and implications 6.1 Conclusion}

The study aimed to examine the relationship between POS, TP and OCB among secondary school teachers in selected schools. There was a positive and significant relationship between: POS and TP, POS and OCB, and TP and OCB. The study also found out that TP partially mediates the relationship between POS and OCB. The present study provides support for the proposition that social exchange theory (SET) is applicable within an education context and that obligation feeling, as a mechanism of reciprocation, is still a key factor in social exchanges. Statistical results revealed that the teachers in these schools display high level of OCB. These teachers are high on Conscientiousness, Courtesy and Altruism.

\subsection{Practical implications}

Majority of the teachers perceive that their schools are supportive in such a way that they agree that their schools 
really care about their well-being and also their opinions. Teachers reciprocated this perceived support with altruism and conscientiousness which are OCB behaviors and high TP in which the teachers adequately complete their assigned duties and also perform essential duties as well. School managers and head teachers need to focus on policies and practices that employees perceive to be supportive and hence lead to improvements in employee $\mathrm{TP}$ and $\mathrm{OCB}$.

Managers should participate in providing support rather than restricting their attention to task-related goals as this will further encourage employees to engage in extra-role activities (OCBs). Head teachers can enhance OCB in schools through recognizing it in management performance reviews, which in turn can be expected to influence merit assessments, salary determinations, and promotion opportunities. School management can also develop OCB by accomplishing POS within their environment. This will help them in enhancing employees' performance, confidence, loyalty and positive attitude towards the school which in turn will increase organizational efficiency. As a result, schools in particular will lead to the path of development and success.

\subsection{Limitations and ethical consideration 7.1 Study limitations}

The research data was obtained using only quantitative methods in the form of questionnaires, which may have limited the strength of the research findings as a single method was used in isolation to gather data. All questionnaires used were of a self-reporting nature. Hence, respondents may have misrepresented themselves while responding to the questions. A form of misrepresentation is the desire to be viewed favorably by others (social desirability), which may have resulted in over-reporting good behaviour or under reporting undesirable behaviour. According to Hair, Babin, Money and Samuel (2003), self-reported questionnaires may result in a loss of researcher support.

The researcher used a non-random sampling technique in the form of convenience sampling to gather data. The drawback is that the results obtained by this technique may not be generalizable (Sekaran, 2001). This is because, the techniques often suffers from biases such as under-representation or over-representation of particular groups within the sample.

The variables were measured by using the same method at a single measurement time (cross-sectional design). Therefore, the common variance bias may have influenced the results (Podsakoff, Mackenzie, Lee, and Podsakoff, 2003). In cross-sectional designs, there might be misrepresentation of the variables that refer to lengthy processes, the effects of which only become apparent over long periods. Furthermore, in cross-sectional research designs, no causal relation between the variables can be inferred. Thus, the results do not allow us to determine the extent to which POS influences the five dimensions of OCB.

\subsection{Ethical considerations}

The researchers made sure that the data are reliable and trustworthy because it is one of the researchers' fundamental responsibility (Katrina, 2013). The researchers made sure that the rights and welfare of the subjects who participated in the study were protected (McMillan and Schumacher, 2011). The researchers ensured confidentiality and anonymity of participants by not revealing their identity. The researchers also sought informed consent by explaining to the respondents the purpose of the research and benefits of the study. This was done to make sure that the participants made an informed decision to either participate in a study or not.

\section{References}

Aghdasi, S., Kiamanesh, A. R., \& Ebrahim, A. N. (2011). Emotional intelligence and organizational commitment: Testing the mediatory role of occupational stress and job satisfaction. Procedia-Social and Behavioral Sciences, 29, 1965-1976.

Allen, T. D., \& Rush, M. C. (1998). The effects of organizational citizenship behavior on performance judgments: a field study and a laboratory experiment. Journal of applied psychology, 83(2), 247.

Allison, B. J., Voss, R. S., \& Dryer, S. (2001). Student classroom and career success: The role of organizational citizenship behavior. Journal of Education for Business, 76(5), 282-288.

Ahmadi, P., Forouzandeh, S., \& Kahreh, M. S. (2010). The relationship between ocb and social exchange constructs. European Journal of Economics, Finance and Administrative Sciences, 19(19), 107-120. Retrieved from http://www.scopus.com/inward/record.url?eid=2-s2.077953973141\&partnerID=40\&md5=49b80d42e1 f0923c9ce34b03ee6d 2 b10

Akcin, K., Erat, S., Alniacik, U., \& Ciftcioglu, A. (2017). Effect Of POSOn Organizational Effect Of POSOn Organizational Silence And Task Performance: A Study on Academicians., 11(1). https://doi.org/10.20460/JGSM.

Argentero, P., Cortese, C. G., \& Ferretti, M. S. (2008). An evaluation of organizational citizenship behavior: Psychometric characteristics of the Italian version of podsakoff et al.'s scale. TPM - Testing, Psychometrics, Methodology in Applied Psychology, 15(2), 61-75. 
Aron, A., Coups, E. J., \& Aron, E. N. (2013). Statistics for Psychology (6th Ed). Upper Saddle River: Pearson. https://doi.org/10.1007/s10876-016-1003-1

Arshadi, N. (2011). Social and The relationships of POS( POS ) with organizational commitment, in-role performance, and turnover intention: Mediating role of felt obligation. Procedia - Social and Behavioral Sciences, 30, 1103-1108.

Baron, R. M., \& Kenny, D. A. (1986). The moderator-mediator variable distinction in social psychological research: Conceptual, strategic, and statistical considerations. Journal of personality and social psychology, 51(6), 1173.

Bogler, R., \& Somech, A. (2004). Influence of teacher empowerment on teachers' organizational commitment, professional commitment and organizational citizenship behavior in schools. Teaching and teacher education, 20(3), 277-289.

Byrne, Z. S., \& Hochwater, W. A. (2008). POSand performance relationships across levels of organizational cynicism. Journal of Managerial Psychology, 23(1), 54-72.

Caesens G., Marique G., Hanin D., Stinglhamber F. (2016). The relationship between perceived organizational support and proactive behaviour directed towards the organization. Eur. J. Work Organ. Psychol. 25, 398-411.

Chiang, C. F., \& Hsieh, T. S. (2012). The impacts of POSand psychological empowerment on job performance: The mediating effects of organizational citizenship behavior. International journal of hospitality management, 31(1), 180-190.

Cropanzano, R., \& Mitchell, M. S. (2005). Social exchange theory: An Interdisciplinary review. Journal of Management, 31(6), 874-900.

Diaz-Vilela, L. F., Rodriguez, N. D., Isla-Diaz, R., Diaz-Cabrera, D., Hernández-Fernaud, E., \& Rosales-Sánchez, C. (2015). Relationships between contextual and task performance and interrater agreement: Are there any?, 10(10), 1-13.

Efron, B. (86). Tibshirani (1993). An introduction to the bootstrap, 57.

Eisenberger, R., Armeli, S., Rexwinkel, B., Lynch, P. D., \& Rhoades, L. (2001). Reciprocation of Perceived Organizational Support. Applied Psychology, 86(1), 42-51.

Eisenberger, R., Cummings, J., Armeli, S., \& Lynch, P. (1997). POS, Discretionary Treatment , and Job Satisfaction, 82(5), 812-820.

Eisenberger, R., Fasolo, P., \& Davis-lamastro, V. (1990). POSand Employee. Journal of Applied Psychology, $75(1), 51-59$

Eisenberger, R., Huntington, R., Utchison, S., \& Sowa, D. (1986). Perceived Organizational Support. Applied Psychology, 71(3), 500-507.

Fouzia, H. A., Sayyid, S. R., Ishfaq, A., \& Madiha, R. (2018). Effects of POSon organizational citizenship behavior-Sequential mediation by well-being and work engagement. Journal of the Punjab University Historical Society, 31(2), 61-71.

Gakovic, A., \& Tetrick, L. E. (2019). Relationships of Part-Time and Full-Time Employees Attending University Classes Linked references are available on JSTOR for this article : POSand work status : a comparison of the employment relationships of part-time and full-time, 24(5), 649-666.

Garg, P., \& Rastogi, R. (2006). New model of job design: motivating employees' performance. Journal of management Development, 25(6), 572-587.

Gouldner, A. W. (1960). The Norm of Reciprocity: A Preliminary Statement. American Sociological Review, $25(2), 161-178$.

Hayes, A. F. (2009). Beyond Baron and Kenny: Statistical mediation analysis in the new millennium. Communication monographs, 76(4), 408-420.

Huitema, B., \& Laraway, S. (2006). Autocorrelation.

Jena, R. K., \& Goswami, R. (2014). Measuring the Determinants of Organizational Citizenship Behaviour. Global Business Review, 15(2), 381-396.

Kour, S. (2014). Ethical and Legal Issues in Educational Research. Indian Journal of Applied Research, 4(6), 133135.

Koys, D. J. (2001). The effects of employee satisfaction, organizational citizenship behavior, and turnover on organizational effectiveness: A unit - level, longitudinal study. Personnel psychology, 54(1), 101-114.

Kurtessis, J. N., Eisenberger, R., Ford, M. T., Buffardi, L. C., Stewart, K. A., \& Adis, C. S. (2015). Perceived Organizational Support: A Meta-Analytic Evaluation of Organizational Support Theory, XX(X), 1-31.

Masterson, S. S., Lewis, K., Goldman, B. M., \& Taylor, M. S. (2000). Integrating Justice and Social Exchange : The Differing Effects of Fair Procedures and Treatment on Work Relationships Author ( s ): Suzanne S . Masterson, Kyle Lewis, Barry M . Goldman and M . Susan Taylor Published by : Academy of Management Stable UR. Academy of Management, 43(4), 738-748.

Miao, R. T. (2011). Perceived Organizational Support, Job Satisfaction, Task Performance and Organizational 
Citizenship Behavior in China. Behaviour and Applied Management, 12(2), 105.

Miao, R., \& Kim, H. G. (2010). Perceived organizational support, job satisfaction and employee performance: An Chinese empirical study. Journal of Service Science and Management, 3(02), 257.

Mohajan, H. (2017). Two Criteria for Good Measurements in Research: Validity and Reliability, 17(3), 58-82.

Monnastes, S. (2010). POSand counterproductive work behavior: How personality moderates the relationship.

Motowildo, S. J., Borman, W. C., \& Schmit, M. J. (1997). A Theory of Individual Differences in Task and Contextual. Human Performance, 2, 71-83.

Nasir, R., Mohammadi, M. S., Wan Shahrazad, W. S., Fatimah, O., Khairudin, R., \& Halim, F. (2011). Relationship Between Organizational Citizenship Behavior and task performance. Social Sciences, 6(4), 307312.

Okeke, T. C., \& Emma-echiegu, N. (2018). Exploratory Analysis of Impact of Organizational Support , and Social Capital on Organizational Citizenship Behaviour ., (February).

Oldham, G. R., \& Cummings, A. (1996). Employee Creativity: Personal and Contextual Factors at Work. The Academy of Management Journal, 39(3), 607-634.

Organ, D. W. (1988). Organizational citizenship behavior: The good soldier syndrome.

Organ, D. W., Podsakoff, P. M., \& MacKenzie, S. B. (2005). Organizational citizenship behavior: Its nature, antecedents, and consequences. Sage Publications.

Osborne, J. W., \& Waters, E. (2002). Four Assumptions of Multiple Regression That Researchers Should Always Test, 8(2), 1-5.

Owens, L. K. (2002). Introduction To Survey Research Design, (January 2002).

Podsakoff, P. M., \& MacKenzie, S. B. (1994). An examination of the psychometric properties and nomological validity of some revised and reduced substitutes for leadership scales. Journal of Applied Psychology, 79(5), 702 .

Podsakoff, M., Mackenzie, S. B., \& Moorman, H. (1990). Leader Behaviors and Their Effects on Followers' Trust In Leader, Satisfaction, and Citizenship Behaviors. The Leadership Quarterly, 1(2), 107-142.

Podsakoff, N. P., Whiting, S. W., Podsakoff, P. M., \& Blume, B. D. (2009). Individual- and Organizational-Level Consequences of Organizational Citizenship Behaviors: A Meta-Analysis. Journal of Applied Psychology, 94(1), 122-141.

Podsakoff, P. M., Mackenzie, S. B., Lee, J., \& Podsakoff, N. P. (2003). Common Method Biases in Behavioral Research : A Critical Review of the Literature and Recommended Remedies. Journa, 88(5), 879-903.

Podsakoff, P. M., Mackenzie, S. B., Paine, J. B., \& Bachrach, D. G. (2000). Organizational Citizenship Behaviors : A Critical Review of the Theoretical and. Journal of Management, 26(3), 513-563.

Preacher, K. J., \& Hayes, A. F. (2008). Asymptotic and resampling strategies for assessing and comparing indirect effects in multiple mediator models. Behavior research methods, 40(3), 879-891.

Pulfrey, C., Darnon, C., \& Butera, F. (2013). Autonomy and task performance: Explaining the impact of grades on intrinsic motivation. Journal of Educational Psychology, 105(1), 39-57.

Rhoades, L., \& Eisenberger, R. (2002). Perceived Organizational Support: A Review of the Literature, 87(4), 698-714.

Riggle, R. J., Edmondson, D. R., \& Hansen, J. D. (2009). A meta-analysis of the relationship between POSand job outcomes: 20 years of research. Journal of business research, 62(10), 1027-1030.

Salahat, M., \& Abdul Halim, A. M. (2017). Does In-Role Performance Mediate the Relationships between Performance Appraisal , Internal Communication and Customer Satisfaction. Journal of Research in Vusiness, Economics and Management (JRBEM), 8(2), 1381-1393.

Saraih, U. N., \& Lim, C. S. (2017). Relationships between task performance, OCB, work deviant behaviour and career satisfaction : Evidences from Health Institution. 3rd International Conference on Advanced Research and Business and Social Sciences 2017, (January), 315-321.

Settoon, R. P., Bennett, N., \& Liden, R. C. (1996). Social exchange in organizations: Perceived organizational support, leader-member exchange, and employee reciprocity. Journal of Applied Psychology, 81(3), $219-227$.

Shaheen, M., Gupta, R., \& Kumar, Y. L. N. (2016). Exploring Dimensions of Teachers' OCB from Stakeholder's Perspective: A Study in India. The Qualitative Report, 21(6), 1095-1117.

Sharma, S. K., \& Agrawal, S. (2015). The Emerging Role of Organizational Citizenship Behaviour in Sustaining Competitve Advantage. Journal of Radix International Educational and Research Consortium, 4(9).

Shore, L. M., \& Shore, T. H. (1995). POSand organizational justice. Organizational politics, justice, and support: Managing the social climate of the workplace, 149, 164.

Shrout, P. E., \& Bolger, N. (2002). Mediation in experimental and nonexperimental studies: new procedures and recommendations. Psychological methods, 7(4), 422.

Sobel, M. E. (1982). Asymptotic confidence intervals for indirect effects in structural equation models. Sociological methodology, 13, 290-312.

Somech, A., \& Ron, I. (2007). Promoting organizational citizenship behavior in schools: The impact of individual 
and organizational characteristics. Educational Administration Quarterly, 43(1), 38-66.

Stamper, C. L., \& Johlke, M. C. (2003). The Impact of POSon the Relationship Between Boundary Spanner Role Stress and Work Outcomes ¿, 29(4), 569-588.

Uçar, D., \& Otken, A. B. (2010). POSand Organizational Commitment: The Mediating Role of Organization Based. Dokuz Eylul Univerisitesi, 2(71), 85-105.

Visser, P. S., Krosnick, J. A., \& Lavrakas, P. J. (1999). Survey research. Annual Review of Psychology, 50(1), 537-567.

Wayne, S. J., Shore, L. M., Bommer, W. H., \& Tetrick, L. E. (2002). The role of fair treatment and rewards in perceptions of organizational support and leader-member exchange. Journal of Applied Psychology, 87(3), 590-598.

Wayne, S. J., Shore, L. M., \& Liden, R. C. (1997). POSand leader-member exchange: A social exchange perspective. Academy of Management Journal, 40(1), 82-111.

Williams, L. J., \& Anderson, S. E. (1991). Job satisfaction and organizational commitment as predictors of organizational citizenship and in-role behaviors. Journal of management, 17(3), 601-617.

Wu Suen, L. J., Huang, H. M., \& Lee, H. H. (2014). A comparison of convenience sampling and purposive sampling. Journal of Nursing, 61(3), 105-111.

Yang, Y., \& Green, S. B. (2011). Coefficient Alpha : A Reliability Coefficient for the 21st Century? Journal of Psychoeducational Assessment. 